\title{
Effect of Different Salinities Levels on Growth and Survival of Indian White Shrimp (Fenneropenaeus indicus)
}

\author{
Jesing G. Vanza ${ }^{1}$, Haresh G. Solanki ${ }^{2}$, Ritesh V. Borichangar ${ }^{2}$, \\ Rajesh B. Vala ${ }^{3}$ and Mihir R. Patel $^{3}$
}

College of Fisheries Science, Navsari Agricultural University, Navsari, Gujarat, India

*Corresponding author

\section{A B S T R A C T}

The present experiment evaluated the effect of different levels of salinities on growth and survival of post larvae (PL) of Fenneropenaeus indicus, commonly known as Indian white shrimp. PL was stocked at six different salinities levels i.e., 15, 20, 25, 3035 and $40 \mathrm{ppt}$

\section{Keywords}

Indian white shrimp, Salinity, Growth survival

Article Info

Accepted:

xx June 2018

Available Online:

xx July 2018 $\left(\mathrm{T}_{1}, \mathrm{~T}_{2}, \mathrm{~T}_{3} \mathrm{~T}_{4}, \mathrm{~T}_{5}\right.$ and $\mathrm{T}_{6}$, respectively) and reared for a period of 60 days. Water quality parameters and growth performance parameters of different treatments were compared during the experiment. A significant $(\mathrm{p}<0.05)$ decrease in growth and survival concentration relative with the higher and lower salinities level was observed. Though some of the parameters showed significant $(\mathrm{p}<0.05)$ difference among the treatments, the water quality remained within optimum level, throughout the experiment. Increase in salinity levels led to significant reduction $(\mathrm{p}<0.05)$ in ABW and survival of PL. Treatment T3 (water salinity $25 \mathrm{ppt}$ ) and treatment T4 (water salinity $30 \mathrm{ppt}$ ) were found at par with each other and significantly better than rest of the treatments in all the periods barring " 0 " DOC. T3 and T4 recorded higher mean body weight at 60 DOC during both the years 2016-17 (0.427 and 0.402 g), 2017-18 (0.577 and 0.505 g) as well as in pooled results $(0.502 \mathrm{~g}$ and $0.454 \mathrm{~g})$ as compared to rest of the treatments. Survival rate of treatment T4 was significantly higher than other treatments while lowest survival was found in treatment T1 and T6.

\section{Introduction}

Shrimp culture in Gujarat is dominated by vannamei shrimp culture because of its higher growth rate than other shrimp species. This species requires low salinity $(15-20 \mathrm{ppt})$ and $28-32^{0} \mathrm{C}$ for their optimum growth. Because of this preference, vannamei shrimp cannot be cultured economically during the winter season and high saline environments. Also, the higher salinity and low temperatures causes stress to vannamei shrimp and ultimately several disease outbreaks are encountered. Because of this reason, the winter crop is a fallow period in Gujarat. The previous year trials of this Indian white shrimp during monsoon and winter season at DantiUmbharat farm and the available literature 
shows that this species can be cultured well during winter season when the salinity remains high and temperature remains low. The salinity range and tolerance of this species is an essential criterion for further refining the culture technology of this species in this region. So the above experiment is proposed.

The successful raising of Indian white shrimp during the monsoon crop during the year 2016 and it's tolerance towards high salinity and low temperatures, have paved the way for a filler trial of this species in this region. The species have shown to thrive under higher salinities during the initial period of stocking yielding approximately $1000 \mathrm{kgs}$ per ha at 10 species stocking density per sq. $\mathrm{m}$.

In shrimp culture system salinity is considered to be the major factor influencing growth and survival.

As per the Kinne (1971) pointed out, salinity is the major environmental factor whereas the temperature fluctuations characteristic to the tropics are not significant. George (1968) also, has proved that salinity, perhaps more than any other, is the single factor affecting shrimps in the brackish water shrimp culture. It is also a factor known to influence the efficiency of a species to utilize the food given (Kalyanaraman and Paul Raj, 1984),

Therefore studies of the responses of the shrimps to the changes in environmental conditions, especially salinity, are essential to determine optimum conditions for successful shrimp farming. High output can be achieved only by exerting control over the environment by reducing stress conditions (Wikins, 1976).

Of the 27 species of shrimps belonging to Penaeidae occurring in Indian coastal waters, 11 species have been reported to be suitable for culture (Rao, 1983). Among these, the Indian white shrimp Penaeus indicu and the black tiger shrimp $P$. monodon are the most popular.

In India, $F$. indicus is one of the prominent species used for semi-intensive shrimp culture. An understanding of the optimal environmental requirements of the species is one of the prime necessities in any culture operation. Brackish water organisms are generally endowed with wide range of adaptability to withstand extreme fluctuations in physical conditions, especially so in the case of salinity. Salinity is a most important factor that is known to influence the efficiency of a species in food utilization and growth (Kalyanaraman and Paul Raj, 1984). Therefore it is necessary to understand the extent of the influence of salinity on the growth and survival by the cultured organism. It is more significant, because growth and survival are one of the major factors in shrimp farming. Hence, it was found necessary to study the effect of salinity on growth and survival on $F$. indicus.

Zein Eldin (1963) found that under conditions of constant temperature and restricted food supply penaeid post larvae survived and grew over a wide range of salinity (2-40 ppt). Earlier studies have highlighted that salinity influences the survival and growth of penaied post larvae and juveniles (Nair and Krishnankutty, 1975; Verghese et al., 1975; Bhattacharya and Kewalramani 1976; Kuttyamma 1982; Lakshmi Kanthan 1982; Raj and Raj, 1982; and Subramanian and Krishnamurthy, 1986).

\section{Materials and Methods}

\section{Experimental site}

The present experiment was conducted for a period of two months (60 days) from Aug to Sep 2016 and 2017 in different levels of salinity at CSSRS (Coastal Soil Salinity 
Research Station) Danti-Umbharat, NAU Navsari.

In this experiment, 24 crate each having an area of $60.5 \mathrm{~cm} \mathrm{x} 40.5 \mathrm{~cm}$ X $33.0 \mathrm{~cm}$ has been setup in the wet laboratory of CSSRS, Danti Umbharat farm. Each crate was fitted with covered at the top to prevent escape of shrimp by jumping and bird predation. The crates were filled with water of different salinities as per the treatments after 72 hrs of bleaching. The whole crates were provided with aeration by air pipe through the aerator.

\section{Shrimp seed stocking:}

In the present study, we tested six different salinities like $15 \mathrm{ppt}, 20 \mathrm{ppt}, 25 \mathrm{ppt}, 30 \mathrm{ppt}, 35$ ppt and 40 ppt as T1, T2, T3, T4, T5 and T6 respectively, four replication for each treatment. All the carets were stocked with $F$. indicus @ 10 pcs. per crate. The seeds received from CIBA hatchery were stocked in the ponds following the standard acclimatization procedure. The seeds were stocked in the morning around $08.00 \mathrm{hrs}$.

In brief, hatchery produced $F$. indicus, averaging $0.092 \pm 0.001 \mathrm{~g}$ (mean \pm SEm) were transported to the experimental site by oxygenated polyethylene bags and they were kept in 1000 lit capacity tank after proper acclimation with environment and then initial length and weight of shrimp seed were recorded individually in ' $\mathrm{cm}$ ' and ' $\mathrm{g}$ ' with the help of a measuring scale and a digital electronic balance respectively. Finally, the seeds were randomly stocked in each crates as per the treatments were recorded simultaneously. During the study period, dead shrimp were recorded and removed quickly. The carets were cleaned by siphoning pipe at every day for cleaning purposes and remove fecal matter and other uneaten feed. The seeds were fed four times a day at a rate of $10 \%$ of body weight.

\section{Sampling and data analysis}

Physico-chemical parameters of water such as temperature $\left({ }^{\circ} \mathrm{C}\right), \mathrm{pH}$, hardness $(\mathrm{mg} / \mathrm{L})$ and total alkalinity $(\mathrm{mg} / \mathrm{L})$ were monitored weekly in the morning between 8 and 9 a.m. during the whole experimental period APHA (1992). Water temperature was recorded with a glass Celsius thermometer, $\mathrm{pH}$ was measured using a digital pocket $\mathrm{pH}$ meter. Other chemical parameters were measured using a titration method.

After 60 days of trial, the whole shrimps were harvested by scoop netting and then shrimps were counted, measured and weighed for each caret. To determine the growth response, yield and survivability of experimental shrimp, the following parameters were calculated:

Weight gain (WG) = final shrimp weight (g)initial shrimp weight $(\mathrm{g})$

Weight gain $(\%)=$ (final weight-initial weight $) \times 100 /$ initial weight

Average daily weight gain $(\mathrm{ADWG})=($ final shrimp weight-initial shrimp weight)/days

\section{Results and Discussion}

\section{Mean periodical weight $(\mathrm{g})$ :}

During the 60 days of experimental period, all the treatment effect was significant on average body weight (g) during individual year as well as in pooled analysis. Treatment $\mathrm{T}_{3}$ (water salinity $25 \mathrm{ppt}$ ) and treatment $\mathrm{T}_{4}$ (water salinity $30 \mathrm{ppt}$ ) were found at par with each other and significantly better than rest of the treatments in all the periods barring " 0 " DOC. $\mathrm{T}_{3}$ and $\mathrm{T}_{4}$ recorded higher mean body weight at 60 DOC during both the years 2016-17 (0.427 and $0.402 \mathrm{~g}), 2017-18$ (0.577 and 0.505

g) as well as in pooled results $(0.502 \mathrm{~g}$ and $0.454 \mathrm{~g}$ ) as compared to rest of the treatments (Table 3 and Fig. 1). 


\section{Mean periodical length $(\mathrm{cm})$}

Periodical mean body length results are reported in table 4 revealed that all the treatment effect was not significant on mean body length $(\mathrm{cm})$ during individual year as well as in pooled analysis. Similar to mean body weight, length also followed the similar trend with treatment $\mathrm{T}_{3}$ (water salinity $25 \mathrm{ppt}$ ) and treatment $\mathrm{T}_{4}$ (water salinity $30 \mathrm{ppt}$ ) were found at par with each other and significantly better than rest of the treatments. $\mathrm{T}_{3}$ and $\mathrm{T}_{4}$ recorded higher mean body length at 60 DOC during both the years 2016-17 (3.995 and $3.880 \mathrm{~cm}), 2017-18(3.623$ and $3.565 \mathrm{~cm})$ as well as in pooled results $(3.809 \mathrm{~cm}$ and 3.723 $\mathrm{cm}$ ) as compared to rest of the treatments (Fig. 2).

\section{Periodical mean survival rates $(\%)$ :}

After 60 days of trial, survival rate of treatment $\mathrm{T}_{4}$ was significantly higher than those from treatments $\mathrm{T}_{1}, \mathrm{~T}_{2}, \mathrm{~T}_{3}, \mathrm{~T}_{5}$ and $\mathrm{T}_{6}$. Survival rate of treatment $\mathrm{T}_{4}$ was significantly higher than other treatments while lowest survival was found in treatment $\mathrm{T}_{1}$ and $\mathrm{T}_{6}$.

Periodical mean survival rate results are reported in table 5 revealed that all the treatment effect were not significant on mean survival rate (\%) during individual year as well as in pooled analysis. Treatment $\mathrm{T}_{4}$ (water salinity $30 \mathrm{ppt}$ ) was found to be significantly better than rest of the treatments in all the periods barring " 0 " DOC. Treatment $\mathrm{T}_{4}$ and $\mathrm{T}_{3}$ recorded higher periodical mean survival rate at $60 \mathrm{DOC}$ during both the years 2016-17 (95.00 \% and 95.00\%), 2017-18 (95.00\% and $92.50 \%)$ as well as in pooled results $(95.00 \%$ and $93.75 \%)$ as compared to rest of the treatments (Table 5 and Fig. 3).

Y X T interaction was found significant in all the periods for mean body weight and mean survival barring mean body weight at " 0 ", " 15 " and "30" DOC. Whereas, the interaction was found significant in all the periods mean body length barring mean body weight at " 0 " DOC. It can be observed from table 3 and 4 that the treatments $T_{3}$ and $T_{4}$ gave consistently better effect than rest of the treatments in all the periods (Mean body weight and mean body length).

The significance of interaction was observed due to inconsistent effect due to treatments other than treatment $\mathrm{T}_{3}$ and $\mathrm{T}_{4}$. Therefore, treatments $T_{3}$ and $T_{4}$ were found to be the best amongst all the treatments for mean body weight, mean body length and survival rate in different periods.

\section{Physico-chemical parameters of water analysis}

The data presented in table 2 showed that there were no significant differences in values amongst the treatments. Weekly water samples were collected from the experiment and analyzed for $\mathrm{pH}$ and alkalinity. Whereas water temperature data like air temperature, surface and bottom were taken on site using thermometer. Physico-chemical parameters at both the locations did not significant variations and within the optimum range.

\section{Economics:}

As $\mathrm{L}$ x $\mathrm{T}$ interaction was not significant, the economics was calculated on the basis of pooled results under investigation. Considering the seed yield of $F$. indicus, cost of feed, cost of labor, per seed cost, gross income, net income and BCR were computed.

The results showed that among the treatments, highest net returns of Rs. $4.92 / \mathrm{m}^{2}$ and Rs. $3.86 / \mathrm{m}^{2}$ was realized with recommended water salinity level $\left(\mathrm{T}_{3}-25 \mathrm{ppt}\right.$ and $\left.\mathrm{T}_{4}-30 \mathrm{ppt}\right)$. The Benefit Cost (BC) ratio per sq. $m$. for the treatment $\mathrm{T}_{3}(1: 1.20)$ is higher than those of all other treatments (Table 6). 
Table.1 Details of experiment

\begin{tabular}{|c|c|c|}
\hline \multirow[t]{2}{*}{ Experimental Details } & \multicolumn{2}{|l|}{ Year } \\
\hline & 2016 & 2017 \\
\hline Date of stocking & 05-08-2016 & $19-9-2017$ \\
\hline Duration of experiment (days) & 60 & 60 \\
\hline Date of observations & $\begin{array}{l}\text { 05/08/2016; 19/08/2016; 03/09/2016; } \\
\text { 18/09/2016; 03/10/2016 }\end{array}$ & $\begin{array}{l}\text { 19/09/2017; 03/10/2017; } \\
\text { 18/10/2017; 02/11/2017; } \\
\text { 17/11/2017 }\end{array}$ \\
\hline Date of harvesting & $03 / 10 / 2016$ & $17 / 11 / 2017$ \\
\hline Water exchange & \multicolumn{2}{|l|}{ Every day @ 50\%. } \\
\hline Feeding schedule & \multicolumn{2}{|l|}{4 times/day @10\% body wt. } \\
\hline
\end{tabular}

Table.2 Water temperature and quality parameters

\begin{tabular}{|c|c|c|c|}
\hline \multirow[t]{2}{*}{ Treatments } & \multirow[t]{2}{*}{ Parameters } & Year 2016 & Year2017 \\
\hline & & \multicolumn{2}{|l|}{ Mean \pm SD } \\
\hline \multirow[t]{3}{*}{$\mathbf{T}_{1}$} & $\mathrm{pH}$ & $8.31 \pm 0.204$ & $8.21 \pm 0.129$ \\
\hline & Alkalinity (ppm) & $194.68 \pm 12.791$ & $198.88 \pm 32.339$ \\
\hline & Temp $\left({ }^{\circ} \mathrm{C}\right)$ & $24.13 \pm 1.264$ & $20.16 \pm 1.152$ \\
\hline \multirow[t]{3}{*}{$\mathbf{T}_{2}$} & $\mathrm{pH}$ & $8.24 \pm 0.245$ & $8.14 \pm 0.055$ \\
\hline & Alkalinity (ppm) & $205.41 \pm 16.255$ & $169.46 \pm 18.618$ \\
\hline & Temp $\left({ }^{\circ} \mathrm{C}\right)$ & $23.81 \pm 1.449$ & $20.69 \pm 1.899$ \\
\hline \multirow[t]{3}{*}{$\mathbf{T}_{\mathbf{3}}$} & $\mathrm{pH}$ & $8.41 \pm 0.195$ & $8.30 \pm 0.163$ \\
\hline & Alkalinity (ppm) & $196.13 \pm 14.186$ & $159.34 \pm 4.926$ \\
\hline & Temp $\left({ }^{\circ} \mathrm{C}\right)$ & $24.16 \pm 1.156$ & $20.41 \pm 1.954$ \\
\hline \multirow[t]{3}{*}{$\mathbf{T}_{4}$} & $\mathrm{pH}$ & $8.18 \pm 0.159$ & $8.13 \pm 0.072$ \\
\hline & Alkalinity (ppm) & $184.44 \pm 23.593$ & $173.31 \pm 21.198$ \\
\hline & Temp $\left({ }^{\circ} \mathrm{C}\right)$ & $24.06 \pm 1.259$ & $21.06 \pm 1.592$ \\
\hline \multirow[t]{3}{*}{$\mathbf{T}_{5}$} & $\mathrm{pH}$ & $8.23 \pm 0.176$ & $8.16 \pm 0.099$ \\
\hline & Alkalinity (ppm) & $203.74 \pm 24.985$ & $173.26 \pm 6.907$ \\
\hline & Temp $\left({ }^{\circ} \mathrm{C}\right)$ & $23.75 \pm 1.277$ & $20.09 \pm 1.216$ \\
\hline \multirow[t]{3}{*}{$T_{6}$} & $\mathrm{pH}$ & $8.21 \pm 0.198$ & $8.11 \pm 0.113$ \\
\hline & Alkalinity (ppm) & $203.44 \pm 15.401$ & $175.80 \pm 17.234$ \\
\hline & $\operatorname{Temp}\left({ }^{\circ} \mathrm{C}\right)$ & $24.19 \pm 1.349$ & $20.56 \pm 1.517$ \\
\hline
\end{tabular}


Table.3 Effect of different treatments on mean weight (g) of Indian white shrimp (mean of 5 nos)

\begin{tabular}{|c|c|c|c|c|c|c|c|c|c|c|c|c|c|c|c|}
\hline \multirow{3}{*}{$\begin{array}{l}\text { Weight (g) } \\
\text { Treatment } \\
\text { /Year }\end{array}$} & \multicolumn{15}{|c|}{ Day of Culture (DOC) } \\
\hline & \multicolumn{3}{|c|}{ O-DOC } & \multicolumn{3}{|c|}{ 15-DOC } & \multicolumn{3}{|c|}{ 30-DOC } & \multicolumn{3}{|c|}{ 45-DOC } & \multicolumn{3}{|c|}{ 60-DOC } \\
\hline & 2016 & 2017 & Pooled & 2016 & 2017 & Pooled & 2016 & 2017 & Pooled & 2016 & 2017 & Pooled & 2016 & 2017 & Pooled \\
\hline T-1 & 0.092 & 0.126 & 0.109 & 0.095 & 0.172 & 0.133 & 0.116 & 0.236 & 0.176 & 0.205 & 0.299 & 0.252 & 0.298 & 0.362 & 0.330 \\
\hline T-2 & 0.091 & 0.127 & 0.109 & 0.099 & 0.183 & 0.141 & 0.128 & 0.258 & 0.193 & 0.230 & 0.304 & 0.267 & 0.333 & 0.350 & 0.342 \\
\hline $\mathbf{T}-3$ & 0.093 & 0.127 & 0.110 & 0.117 & 0.209 & 0.163 & 0.166 & 0.295 & 0.230 & 0.277 & 0.413 & 0.345 & 0.427 & 0.577 & 0.502 \\
\hline T-4 & 0.091 & 0.125 & 0.108 & 0.105 & 0.194 & 0.149 & 0.139 & 0.276 & 0.208 & 0.252 & 0.391 & 0.322 & 0.402 & 0.505 & 0.454 \\
\hline T-5 & 0.091 & 0.125 & 0.108 & 0.101 & 0.177 & 0.139 & 0.133 & 0.248 & 0.190 & 0.235 & 0.312 & 0.274 & 0.359 & 0.376 & 0.367 \\
\hline T-6 & 0.092 & 0.127 & 0.109 & 0.099 & 0.170 & 0.135 & 0.126 & 0.243 & 0.184 & 0.220 & 0.282 & 0.251 & 0.314 & 0.321 & 0.318 \\
\hline SEm \pm & 0.001 & 0.001 & 0.001 & 0.001 & 0.005 & 0.003 & 0.002 & 0.006 & 0.003 & 0.002 & 0.005 & 0.017 & 0.003 & 0.005 & 0.029 \\
\hline CD@ 5\% & NS & NS & NS & 0.003 & 0.014 & 0.008 & 0.006 & 0.002 & 0.009 & 0.007 & 0.016 & 0.060 & 0.008 & 0.015 & 0.105 \\
\hline CV (\%) & 1.92 & 1.41 & 1.63 & 2.49 & 5.14 & 4.83 & 3.02 & 4.21 & 4.18 & 1.91 & 3.14 & 2.83 & 1.44 & 2.47 & 2.10 \\
\hline \multirow[t]{2}{*}{ YXT } & SEm \pm & $\begin{array}{c}\text { CD@ } \\
5 \%\end{array}$ & & SEm \pm & $\begin{array}{c}\text { CD @ } \\
5 \%\end{array}$ & & SEm \pm & $\begin{array}{c}\text { CD@ } \\
5 \%\end{array}$ & & SEm \pm & $\begin{array}{c}\text { CD@ } \\
5 \%\end{array}$ & & SEm \pm & $\begin{array}{c}\text { CD @ } \\
5 \%\end{array}$ & \\
\hline & 0.001 & NS & & 0.004 & NS & & 0.004 & NS & & 0.004 & 0.012 & & 0.004 & 0.012 & \\
\hline
\end{tabular}

* Value in the parenthesis are original mean value 
Table.4 Effect of different treatments on mean length $(\mathrm{cm})$ of Indian white shrimp (mean of 5 nos)

\begin{tabular}{|c|c|c|c|c|c|c|c|c|c|c|c|c|c|c|c|}
\hline Length & \multicolumn{15}{|c|}{ Day of Culture (DOC) } \\
\hline \multirow{2}{*}{$\begin{array}{l}\text { Treatment } \\
\text { /Year }\end{array}$} & \multicolumn{3}{|c|}{ O-DOC } & \multicolumn{3}{|c|}{ 15-DOC } & \multicolumn{3}{|c|}{ 30-DOC } & \multicolumn{3}{|c|}{ 45-DOC } & \multicolumn{3}{|c|}{ 60-DOC } \\
\hline & 2016 & 2017 & Pooled & 2016 & 2017 & Pooled & 2016 & 2017 & Pooled & 2016 & 2017 & Pooled & 2016 & 2017 & Pooled \\
\hline T-1 & 2.515 & 2.955 & 2.735 & 2.605 & 3.095 & 2.850 & 2.800 & 3.241 & 3.021 & 3.010 & 3.390 & 3.200 & 3.370 & 3.543 & 3.456 \\
\hline T-2 & 2.525 & 2.975 & 2.750 & 2.685 & 3.093 & 2.889 & 2.960 & 3.248 & 3.104 & 3.330 & 3.388 & 3.359 & 3.750 & 3.530 & 3.640 \\
\hline T-3 & 2.530 & 2.955 & 2.743 & 2.640 & 3.080 & 2.860 & 2.990 & 3.335 & 3.163 & 3.395 & 3.528 & 3.461 & 3.995 & 3.623 & 3.809 \\
\hline T-4 & 2.550 & 2.990 & 2.770 & 2.810 & 3.125 & 2.967 & 3.135 & 3.295 & 3.215 & 3.460 & 3.468 & 3.464 & 3.880 & 3.565 & 3.723 \\
\hline T-5 & 2.545 & 2.970 & 2.756 & 2.765 & 3.060 & 2.913 & 3.045 & 3.220 & 3.133 & 3.385 & 3.345 & 3.365 & 3.780 & 3.472 & 3.626 \\
\hline T-6 & 2.535 & 2.980 & 2.758 & 2.735 & 3.112 & 2.923 & 3.065 & 3.268 & 3.166 & 3.365 & 3.390 & 3.378 & 3.560 & 3.510 & 3.535 \\
\hline SEm \pm & 0.016 & 0.017 & 0.011 & 0.024 & 0.023 & 0.037 & 0.025 & 0.028 & 0.055 & 0.025 & 0.023 & 0.076 & 0.025 & 0.020 & 0.104 \\
\hline CD@ 5\% & NS & NS & NS & 0.072 & NS & NS & 0.075 & NS & NS & 0.075 & 0.068 & NS & 0.074 & 0.060 & NS \\
\hline CV $(\%)$ & 1.25 & 1.15 & 1.19 & 1.79 & 1.46 & 1.61 & 1.69 & 1.71 & 1.70 & 1.52 & 1.33 & 1.42 & 1.33 & 1.14 & 1.25 \\
\hline \multirow[t]{2}{*}{ YXT } & SEm \pm & $\begin{array}{c}\text { CD@ } \\
5 \%\end{array}$ & & SEm \pm & $\begin{array}{c}\text { CD @ } \\
5 \%\end{array}$ & & SEm \pm & $\begin{array}{c}\text { CD @ } \\
5 \%\end{array}$ & & SEm \pm & $\begin{array}{c}\text { CD @ } \\
5 \%\end{array}$ & & SEm \pm & $\begin{array}{c}\text { CD@ } \\
5 \%\end{array}$ & \\
\hline & 0.016 & NS & & 0.023 & 0.067 & & 0.027 & 0.077 & & 0.024 & 0.069 & & 0.023 & 0.065 & \\
\hline
\end{tabular}

* Value in the parenthesis are original mean value 
Table.5 Effect of different treatments on survival (\%) of Indian white shrimp (mean of 5 nos)

\begin{tabular}{|c|c|c|c|c|c|c|c|c|c|c|c|c|c|c|c|}
\hline Survival & \multicolumn{15}{|c|}{ Day of Culture (DOC) } \\
\hline Treatment/ & \multicolumn{3}{|c|}{ O-DOC } & \multicolumn{3}{|c|}{ 15-DOC } & \multicolumn{3}{|c|}{ 30-DOC } & \multicolumn{3}{|c|}{ 45-DOC } & \multicolumn{3}{|c|}{ 60-DOC } \\
\hline Year & 2016 & 2017 & Pooled & 2016 & 2017 & Pooled & 2016 & 2017 & Pooled & 2016 & 2017 & Pooled & 2016 & 2017 & Pooled \\
\hline T-1 & 100 & 100 & 100 & 87.50 & 92.50 & 90.00 & 80.00 & 77.50 & 78.75 & 77.50 & 52.50 & 65.00 & 75.00 & 50.00 & 62.50 \\
\hline T-2 & 100 & 100 & 100 & 90.00 & 95.00 & 92.50 & 85.00 & 87.50 & 86.25 & 85.00 & 85.00 & 85.00 & 82.50 & 72.50 & 77.50 \\
\hline T-3 & 100 & 100 & 100 & 97.50 & 100.00 & 98.75 & 95.00 & 100.00 & 97.50 & 95.00 & 95.00 & 95.00 & 95.00 & 92.50 & 93.75 \\
\hline T-4 & 100 & 100 & 100 & 97.50 & 100.00 & 98.75 & 95.00 & 97.50 & 96.25 & 95.00 & 97.50 & 96.25 & 95.00 & 95.00 & 95.00 \\
\hline T-5 & 100 & 100 & 100 & 95.00 & 97.50 & 96.25 & 92.50 & 87.50 & 90.00 & 90.00 & 90.00 & 83.75 & 85.00 & 65.00 & 75.00 \\
\hline T-6 & 100 & 100 & 100 & 85.00 & 90.00 & 87.50 & 82.50 & 77.50 & 80.00 & 77.50 & 77.50 & 72.50 & 72.50 & 55.00 & 63.75 \\
\hline SEm \pm & 0.000 & 0.000 & 0.000 & 2.946 & 1.863 & 1.651 & 4.167 & 2.826 & 2.476 & 4.167 & 4.249 & 5.244 & 4.330 & 3.436 & 5.000 \\
\hline CD@ 5\% & NS & NS & NS & 8.754 & 5.537 & 4.715 & NS & 8.397 & 7.072 & 12.38 & 12.625 & 19.067 & 12.86 & 10.209 & 18.178 \\
\hline CV $(\%)$ & 0.00 & 0.00 & 0.00 & 6.40 & 6.89 & 5.25 & 9.43 & 6.43 & 8.08 & 9.62 & 10.73 & 10.15 & 10.29 & 9.59 & 10.03 \\
\hline \multirow[t]{2}{*}{ YXT } & SEm \pm & $\begin{array}{c}\text { CD @ } \\
5 \%\end{array}$ & & SEm \pm & $\begin{array}{c}\text { CD @ } \\
5 \%\end{array}$ & & SEm \pm & $\begin{array}{c}\text { CD @ } \\
5 \%\end{array}$ & & SEm \pm & $\begin{array}{c}\text { CD @ } \\
5 \%\end{array}$ & & SEm \pm & $\begin{array}{c}\text { CD@ } \\
5 \%\end{array}$ & \\
\hline & 0.000 & NS & & 2.465 & NS & & 6.560 & NS & & 4.208 & 12.077 & & 3.909 & 11.218 & \\
\hline
\end{tabular}

Table.6 Economics cost of production (per sq.m. basis)

\begin{tabular}{|c|c|c|c|c|c|c|c|c|c|c|c|c|}
\hline Treatments & $\begin{array}{c}\text { Average } \\
\text { biomass per } \\
\text { crate (g) }\end{array}$ & $\begin{array}{c}\text { Biomass } \\
\text { (g) per } \\
\text { m }^{2}\end{array}$ & $\begin{array}{c}\text { Total } \\
\text { Feed } \\
(\mathrm{g})\end{array}$ & Sale (Rs) & $\begin{array}{l}\text { Seed } \\
\text { cost } \\
(\mathbf{R s})\end{array}$ & $\begin{array}{l}\text { Feed } \\
\text { cost } \\
(\mathbf{R s})\end{array}$ & $\begin{array}{c}\text { Total } \\
\text { operational } \\
\text { costs (Rs) }\end{array}$ & $\begin{array}{l}\text { Gross } \\
\text { income } \\
\text { (Rs) }\end{array}$ & $\begin{array}{c}\text { Net } \\
\text { income } \\
(\mathbf{R s})\end{array}$ & $\begin{array}{c}\mathrm{BC} \\
\text { ratio }\end{array}$ & $\begin{array}{l}\text { per kg cost } \\
\text { of } \\
\text { production }\end{array}$ & FCR \\
\hline $\mathbf{T}_{1}$ & 1.32 & 5.39 & 9.8 & 2.15 & 3.00 & 0.181 & 3.181 & -1.03 & -4.21 & -1.32 & 0.591 & 7.39 \\
\hline $\mathbf{T}_{2}$ & 2.74 & 11.16 & 11.4 & 4.46 & 3.00 & 0.375 & 3.375 & 1.09 & -2.29 & -0.68 & 0.302 & 4.17 \\
\hline $\mathbf{T}_{\mathbf{3}}$ & 8.04 & 32.81 & 15.5 & 13.12 & 3.00 & 1.102 & 4.102 & 9.02 & 4.92 & 1.20 & 0.125 & 1.93 \\
\hline $\mathbf{T}_{4}$ & 7.26 & 29.61 & 14.2 & 11.85 & 3.00 & 0.995 & 3.995 & 7.85 & 3.86 & 0.97 & 0.135 & 1.96 \\
\hline $\mathbf{T}_{\mathbf{5}}$ & 2.94 & 12.00 & 12.4 & 4.80 & 3.00 & 0.403 & 3.403 & 1.40 & -2.01 & -0.59 & 0.284 & 4.22 \\
\hline $\mathbf{T}_{6}$ & 1.27 & 5.19 & 10.0 & 2.07 & 3.00 & 0.174 & 3.174 & -1.10 & -4.27 & -1.35 & 0.612 & 7.87 \\
\hline
\end{tabular}

Seed cost - Rs. 0.30/ PL animal

Feed cost - Rs. 84 Rs/kg

Shrimp market price- Rs. 400 Rs/kg

\section{Assumptions:-}

1. Labour cost is not taken into considerations as it is common for all the treatments

2. All shrimps in the treatments are assumed to survived at the end of experiment

3. The biomass is calculated on 1 sq. $\mathrm{m}$. basis 
Figure.1 Mean body weight (g) of Indian white shrimp at different salinity levels (pooled data)

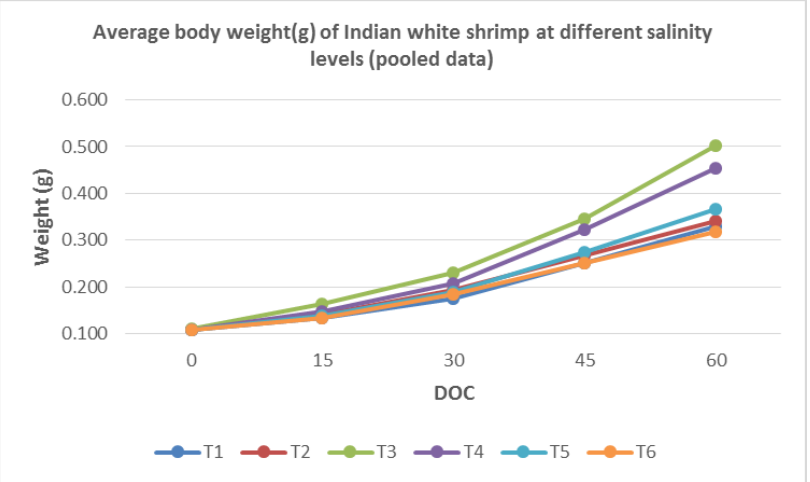

Figure.2 Mean body length $(\mathrm{cm})$ Indian white shrimp at different salinity levels (pooled data)

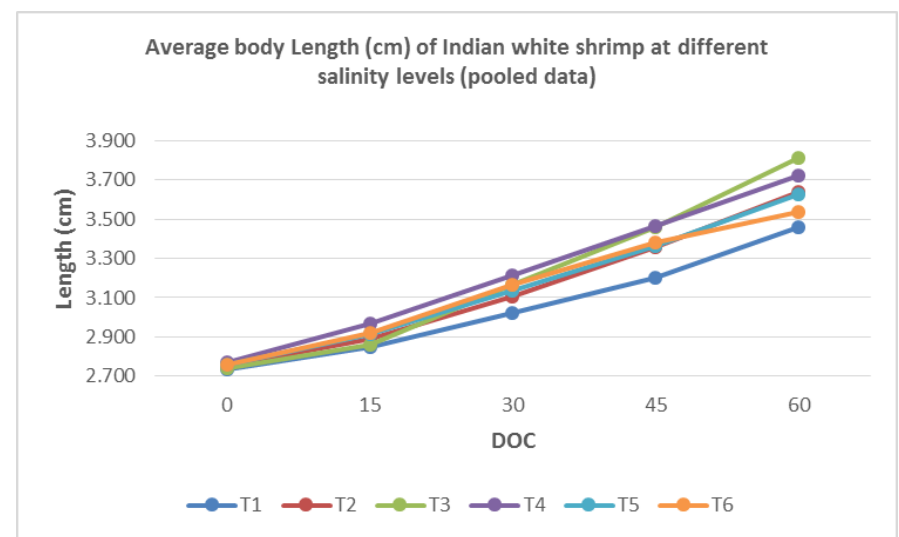

Figure.3 Mean survival rate (\%) of Indian white shrimp at different salinity levels (pooled data)

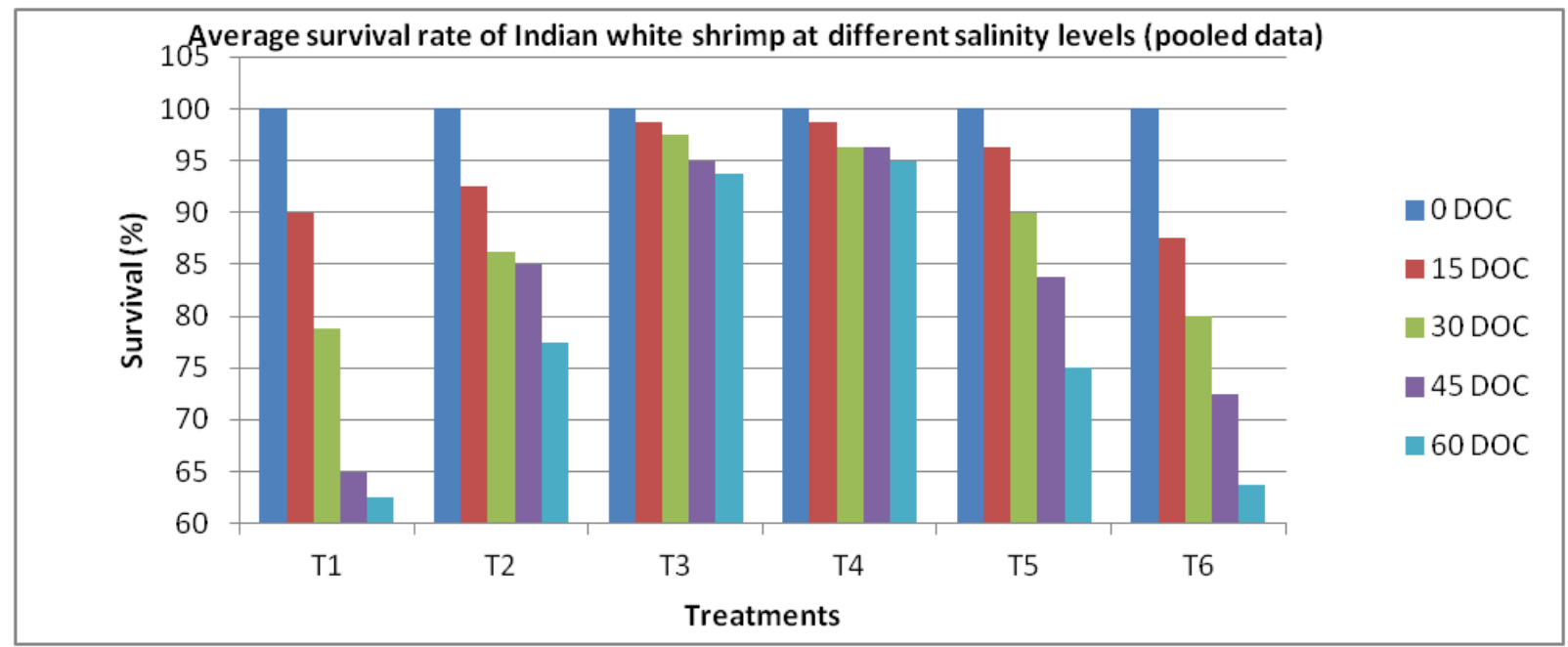


Based on the pooled results of two years, following conclusion is emerged. For Indian white shrimp culture in brackish water ponds in the coastal areas, for getting optimum growth survival and production, water salinity of 25-30 ppt is suitable for getting higher benefit.

\section{Acknowledgment:}

The author thanks H.G. Solanki and other scientist who are helping for setup and running of experiment. We thank Krishna, Kirit, Mintesh, Mahesh to monitoring, collecting and analysis of the data of experiment. We thank all the people who are helping directly or indirectly for the successful of this study.

\section{References}

Kinne, O. 1971. Salinity: AnimalsInvertebrates. Ecology, Vol. I, Part 2, O.Kinne (ed.).

Science, London. pp. 821-995.

George, M.J., 1968. The influence of backwaters and estuaries on marine prawn resources. Proc. Symp. on Living Resources of the Seas around India., ICAR, CMFRI, 563-569.

Kalyanaraman, M. and Paul Raj, R. 1984. Effect of salinity on food intake, growth, conversion efficiency and proximate composition of juvenile Penaeus indicus H. Milne Edwards. CMFRI, Special Publication No. 19, 2629.

Wikins, J.F. 1976. Prawn biology and culture. In: H. Barnes (Ed.) Annual Review Oceanogr. Mar. Bioi., 14, 435-507.

Rao, R.M. 1983. Shrimp seed resources of India. Proc. Natl. Symposium on Shrimp seed Production and Hatchery Management. MPEDA, Cochin, 49-67.

Zein-Eldin, Z.P. 1963. Effect of salinity on growth of post-larval penaeid shrimp. BioI. Bull. Mar. BioI. Lab., Woods Hole, 125: 188-196.

Nair, S.R.S. and Krishnankutty, M.K. 1975. Notes on the varying effects of salinity on the growth of the juveniles of Penaeus indicus from the Cochin backwater. Bull. Dept. Mar. Sci. Univ. Cochin, 7 (1): 181-184.

Verghese, P.U., Ghosh, A.W. and Das, P.B. 1975. On growth, survival and production of Jumbo tiger prawn Penaeus monodon FabriciuB in brackish water ponds. Univ. Cochin, 7(4): 781789.

Bhattacharya, S.S. and Kewalramani, H.G. 1976. Salinity and temperature tolerance of post-larvae of Penaeus indicus. J. Ind. Fish. Assoc., 182: 105-113.

Kuttyamma, V.J., 1982. The effects of salinity on the growth of some penaeid prawns. Bull. Mar. Sci. Univ. Cochin, 13: 1-34.

Lakshmikanthan, K.P. 1982. Salinity tolerance of post larvae of Penaeus indicus $\mathrm{H}$. Milne Edwards. Ph.D. Thesis, Cochin University of Science and Technology, Cochin.

Raj, R.P. and Raj, P.J.S. 1982. Effect of salinity on growth and survival of three species of penaeid prawns. Coastal Aquaeulture, Part I: 236-243.

Subramanian, P. and Krishnamurthy, K. 1986. Effects of salinity and body size on metabolism and growth of juvenile penaeid prawns. Indian J. Exp. BioI., 24 (12): 773-778.

\section{How to cite this article:}

Jesing G. Vanza, Haresh G. Solanki, Ritesh V. Borichangar, Rajesh B. Vala, Mihir R. Patel. 2018. Effect of Different Salinities Levels on Growth and Survival of Indian White Shrimp (Fenneropenaeus Indicus) Int.J.Curr.Microbiol.App.Sci. 7(07): 2295-2304. doi: https://doi.org/10.20546/ijcmas.2018.707.268 